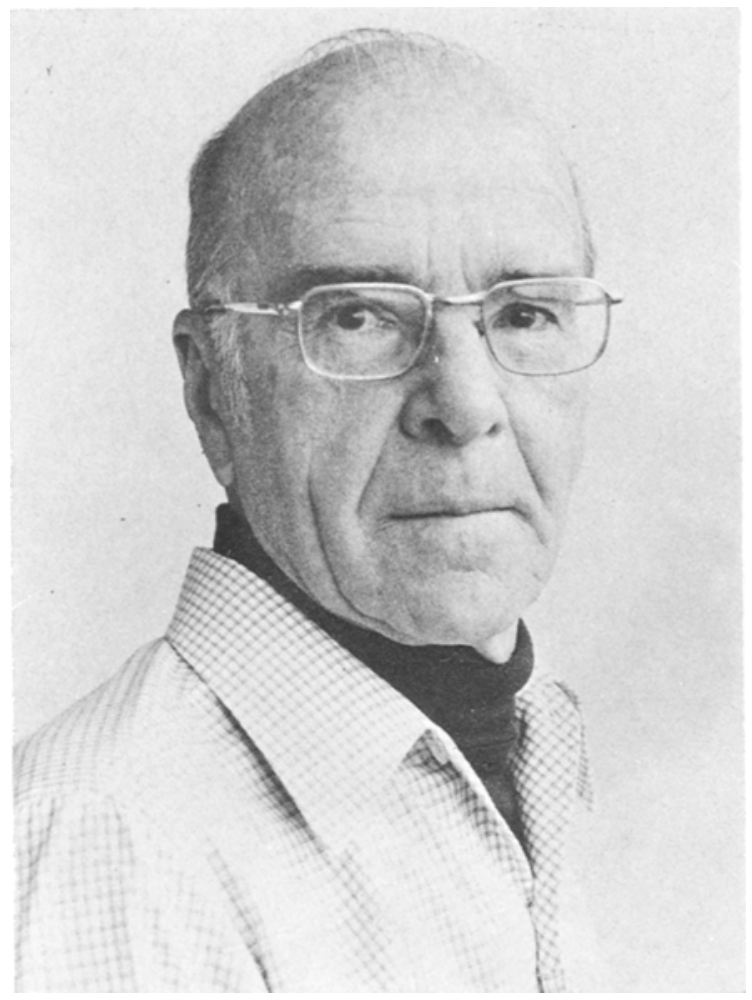

Die Geologische Vereinigung verleiht im Jahre 1980 die Gustav-Steinmann-Medaille an

\title{
PROFESSOR DR. HENNO MARTIN
}

in Würdigung seiner grundlegenden Arbeiten

über das Werden und Auseinanderbrechen des Gondwana-Kontinents, welche das Wissen um die Mechanismen alter und junger Globaltektonik wesentlich erweiterten 